\title{
PENGARUH MEDIA PEMBELAJARAN DENGAN AUDIO VISUAL TERHADAP TINGKAT KOMPETENSI MAHASISWA DALAM PEREKAMAN EKG
}

\author{
Sugiyarto \\ Politeknik Kesehatan Surakarta Jurusan Keperawatan
}

\begin{abstract}
Audio Visual Learning, Competence, ECG Recording. This study aimed to determine the affect of audio-visual learning media to the level of students' competences of ECG recording. This research is a quantitative study with Quasy Experimental methods. The research design of this study used pre-test and post-test control group. The numbers of respondents were 44 nursing students of Poltekkes Surakarta. Dependent Test is used to pre-test and post-test in treatment groups and also pre-test and post-test in control group if data distributed normally, if not normal using Wilcoxon. Independent $T$ tests is used to post-test in treatment and control group if data distributed normally, if not normal using Mann Whitney. Normality test data used Kolmogor-Smirnov. The P value of treatment and control groups, before and after the intervention, were similiar (0.000), $P$ value $<0.05$. The conclusion of this study was audio-visual learning media has better effect on students' competences of ECG recording than using phantom media. So that, educators are expected to use audiovisual learning media as their learning media for students. Students are expected to have better skills in nursing services.
\end{abstract}

Keyword: Audio Visual Learning, Competence, ECG Recording.

Abstrak: Pembelajaran Audio Visual, Tingkat kompetensi, Perekaman EKG. Penelitian ini bertujuan untuk Untuk mengetahui pengaruh media pembelajaran dengan audio visual terhadap tingkat kompetensi mahasiswa dalam perekaman EKG. Penelitian ini merupakan penelitian kuantitatif dengan menggunakan metode Quasy Experimental dan desain penelitian menggunakan pre test dan post test control group. Penelitian ini melibatkan 44 responden yang berasal dari mahasiswa jurusan keperawatan. Analisa data untuk menguji pre dan post pada kelompok perlakuan serta pre dan post pada kelompok kontrol adalah Uji $t$ Dependent jika data terdistribusi normal, jika tidak normal menggunakan Wilcoxon. Analisa data untuk menguji post pada kelompok perlakukan dan kontrol adalah Uji t Independent jika data terdistribusi normal, jika tidak normal menggunakan Mann Whitney. Uji normalitas data menggunakan KolmogorSmirnov. nilai $\mathrm{p}$ value kelompok kontrol dan perlakuan setelah dan sebelum intervensi adalah sama-sama 0.000 hal ini berarti $\mathrm{p}$ value $<0.05$. Hal ini berarti penggunaan media pembelajaran dengan audio visual memiliki pengaruh yang lebih baik pada kemampuan mahasiswa dalam melakukan perekama EKG dibanding dengan menggunakan media pembelajaran phantom. Rekomendasi bagi pendidik dapat dijadikan data awal untuk melakukan penelitian lain terkait metode pembelajaran yang tepat.Bagi pendidik diharapkan dapat menerapkan media pembelajaran audio-visual dalam melakukan pembelajaran pada mahasiswa. 
Kata Kunci: Pembelajaran Audio Visual, Tingkat kompetensi, Perekaman EKG

\section{PENDAHULUAN}

Pemerolehan pengetahuan dan keterampilan, perubahan-perubahan sikap dan prilaku dapat terjadi karena interaksi antara pengalaman baru dengan pengalaman yang pernah dialami sebelumnya. Menurut Bunner (1966) yang dikutib Azhar ada tiga tingkatan utama modus belajar yaitu : Pertama pengalaman langsung (enative), adalah mengerjakan, misalnya arti kata simpul dipahami langsung dengan membuat simpul. Kedua pegalaman piktorial/ gambar (iconic), adalah pengalaman yang diperoleh melalui gambar, misalnya kata simpul dipelajari dari gambar, lukisan foto, atau film meskipun siswa belum pernah mengikat tali untuk membuat simpul mereka dapat mempelajari dan memahami dari gambar tersebut. Ketiga pengalaman abstrak (symbolic), adalah pembacaan kata simpul dan mencocokkan dengan simpul pada image mental atau mencocokkannya dengan pengalamannya membuat simpul. Ketiga tingkatan pengalaman ini saling berinteraksi dalam upaya memperoleh pengalaman (pengetahuan, keterampilan dan sikap) yang baru (Azhar, 2005).

Agar proses belajar mengajar dapat berhasil dengan baik, siswa sebaiknya diajak untuk memanfaatkan semua alat inderanya. Guru berupaya untuk menampilkan rangsangan (stimulus) yang dapat diproses dengan berbagai indra. Semakin banyak alat indra yang digunakan untuk menerima dan mengolah informasi tersebut, maka informasi akan dapat bertahan dan tesimpan dalam ingatan (Azhar, 2005).
Pembelajaran setiap manusia memiliki kemampuan yang berbeda-beda. Ada yang unggul dalam aspek verbal dan ada yang unggul dalam aspek non verbal. Oleh karena itu, Edgar Dale dalam Azhar Arsyad mengemukakan bahwa prosentase keberhasilan pembelajaran sebesar $75 \%$ berasal dari indera pandang, melalui indera dengar sebesar $13 \%$ dan melalui indera lainnya sebesar 12\% (Azhar, 2005).

Kelebihan media belajar adalah menarik indera dan menarik minat, karena merupakan gabungan antara pandang, suara, dan gerakan. Lembaga Riset dan Penerbitan Komputer yaitu Computer Technology Research (CTR) menyatakan bahwa orang hanya mampu mengingat $20 \%$ dari yang dilihat, dan $30 \%$ dari yang didengar. Tetapi orang dapat mengingat $50 \%$ dari yang dilihat dan didengar dan $80 \%$ dari yang dilihat, didengar, dan dilakukan sekaligus (Suyanto, 2003).

Mahasiswa Jurusan keperawatan di Poltekkes Surakarta tingkat 2 semester 3 terdiri dari 6 kelas, 4 kelas prodi D3 Keperawatan dan 2 kelas prodi D4 Keperawatan. Mahasiswa yang sedang menjalani perkuliahan semester 3 mendapatkan mata kuliah Keperawatan Medikal Bedah I dan salah satu kompetensinya adalah mahasiswa mampu melakukan tindakan perekaman EKG. Sebelum mereka memasuki ranah rumah sakit mereka harus memiliki beberapa kompetensi. Salah satu kompetensi yang harus dimiliki mahasiswa adalah kompetensi mengenai perekaman EKG (elektrocardiografi). Agar mahasiswa mampu memiliki kompetensi yang baik maka media yang digunakan dalam 
mengajarkan kompetensi tersebut harusnya tepat.

EKG adalah suatu grafik yang menggambarkan rekaman listrik jantung. Kegiatan listrik jantung dalam tubuh dapat dicatat dan direkam melalui elektrodaelektroda yang dipasang pada permukaan tubuh. Kelainan tata listrik jantung akan menimbulkan kelainan gambar EKG. Pemeriksaan EKG menjadi pemeriksaan diagnostik yang penting. Saat ini pemeriksaan jantung tanpa pemeriksaan EKG dianggap kurang lengkap. Beberapa kelainan jantung sering hanya diketahui berdasarkan EKG saja. Tetapi sebaliknya juga, jangan memberikan penilaian yang berlebihan pada hasil pemeriksaan EKG dan mengabaikan anamnesis dan pemeriksaan fisik (Dharma, 2010).

Berdasarkan uraian latar belakang di atas maka peneliti tertarik untuk melakukan penelitian tentang" Pengaruh Media Pembelajaran Dengan Audio Visual Terhadap Tingkat Kompetensi Mahasiswa Dalam Perekaman EKG"

\section{METODE PENELITIAN}

Penelitian ini

menggunakan metode Quasy

Experimental dan desain penelitian

menggunakan pre test dan post test control group (Sugiyono, 2012). Respoden akan dibagi kedalam dua kelompok yaitu kelompok perlakuan dan kelompok kontrol. Kelompok perlakuan merupakan kelompok yang diberikan intervensi dan kelompok kontrol merupakan kelompok pembanding. Semua kelompok akan dilakukan penilian awal (pretest) dan setelah perlakukan akan dilakukan penilaian (posttest).

\section{HASIL PENELITIAN}

Penelitian ini dilakukan kepada 44 mahasiswa kelas II B Prodi D4 keperawatan, Jurusan Keperawatan Poltekkes Kemenkes Surakarta kemudian dibagi dalam dua kelompok, yaitu kelompok intervensi dan kelompok kontrol, masing- masing kelompok berjumlah 22 mahasiswa.

Tabel 1

Karakteristik responden

\begin{tabular}{|c|c|c|c|c|}
\hline \multirow[t]{2}{*}{ Variabel } & \multicolumn{2}{|c|}{ Intervensi } & \multicolumn{2}{|c|}{ Kontrol } \\
\hline & $\begin{array}{c}\text { Frek. } \\
\text { (mean) }\end{array}$ & $\begin{array}{c}\text { Presentase } \\
(\%)\end{array}$ & $\begin{array}{c}\text { Frek. } \\
\text { (mean) }\end{array}$ & $\begin{array}{c}\text { Presentase } \\
(\%)\end{array}$ \\
\hline $\begin{array}{l}\text { Usia } \\
\text { (tahun) }\end{array}$ & 18,95 & & 19,18 & \\
\hline 17 & 1 & 4 & 0 & 0 \\
\hline 18 & 3 & 14 & 2 & 9 \\
\hline 19 & 14 & 64 & 15 & 68 \\
\hline 20 & 4 & 18 & 4 & 18 \\
\hline 21 & 0 & 0 & 1 & 5 \\
\hline Jumlah & 22 & 100 & 22 & 100 \\
\hline \multirow{2}{*}{\multicolumn{5}{|c|}{$\begin{array}{l}\text { Jenis } \\
\text { Kelamin }\end{array}$}} \\
\hline & & & & \\
\hline Perempuan & 19 & 86 & 19 & 86 \\
\hline Laki-laki & 3 & 14 & 3 & 14 \\
\hline Jumlah & 22 & 100 & 22 & 100 \\
\hline
\end{tabular}

diketahui bahwa paling banyak responden berusia 19 tahun yaitu sebanyak 14 orang (64\%) pada kelompok perlakuan dan 15 orang $(68 \%)$ pada kelompok kontrol. Sedangkan jenis kelamin paling banyak adalah perempuan yaitu 19 orang (86 \%) dan laki-laki hanya 3 orang (14\%), baik pada kelompok perlakuan maupun kelompok kontrol.

Sebelum dilakukan intervensi semua responden tidak kompeten dalam melakukan tindakan perekaman EKG. Setelah dilakukan intervensi pembelajaran menggunakan phantom semua responden sangat kompeten dalam melakukan tindakan perekaman EKG. Data tentang 
nilai mahasiswa sebelum dan setelah intervensi dapat dilihat pada tabel 2 .

\section{Tabel 2}

Nilai Perekaman EKG Sebelum dan Setelah Intervensi Kelompok Kontrol

\begin{tabular}{rcccc}
\hline Nilai & Frek. & Mean & $\begin{array}{c}\text { Std. } \\
\text { Dev. }\end{array}$ & $\begin{array}{c}\text { Presentase } \\
(\%)\end{array}$ \\
\hline Sebelum & & & & \\
20 & 1 & 40.00 & 6.90 & 5 \\
30 & 2 & & & 9 \\
40 & 15 & & & 68 \\
50 & 4 & & & 18 \\
& & & & 100 \\
Jumlah & 22 & & & \\
& & & & \\
Setelah & & & 3.29 & 9 \\
78 & 2 & 82.09 & & 41 \\
80 & 9 & & & 9 \\
81 & 2 & & & 5 \\
83 & 1 & & & 22 \\
84 & 5 & & & 5 \\
85 & 1 & & & 9 \\
90 & 2 & & & \\
& & & & 100 \\
Jumlah & 22 & & & \\
& & &
\end{tabular}

Berdasarkan tabel 2 menunjukkan bahwa nilai rata-rata mahasiswa dalam perekaman EKG sebelum dilakukan intervensi pembelajaran dengan menggunakan phantom pada kelompok kontrol adalah 40 dan setelah intervensi 82.09 .

Sebelum dilakukan intervensi semua responden tidak kompeten dalam melakukan tindakan perekaman EKG. Setelah dilakukan intervensi pembelajaran menggunakan phantom semua responden sangat kompeten dalam melakukan tindakan perekaman EKG. Data tentang nilai mahasiswa sebelum dan setelah intervensi dapat dilihat pada tabel 3.
Tabel 3

Nilai Perekaman EKG Sebelum dan Setelah Intervensi Kelompok Perlakuan

\begin{tabular}{|c|c|c|c|c|}
\hline Nilai & Frekuensi & Mean & $\begin{array}{c}\text { Std. } \\
\text { Deviation }\end{array}$ & $\begin{array}{c}\text { Presentase } \\
(\%)\end{array}$ \\
\hline \multicolumn{5}{|l|}{ Sebelum } \\
\hline 20 & 3 & 37.27 & 8.27 & 14 \\
\hline 30 & 2 & & & 9 \\
\hline 40 & 15 & & & 68 \\
\hline 50 & 2 & & & 9 \\
\hline Jumlah & 22 & & & 100 \\
\hline \multicolumn{5}{|l|}{ Setelah } \\
\hline 80 & 7 & 85.77 & 4.77 & 32 \\
\hline 85 & 3 & & & 14 \\
\hline 86 & 4 & & & 18 \\
\hline 90 & 6 & & & 27 \\
\hline 94 & 2 & & & 9 \\
\hline Jumlah & 22 & & & 100 \\
\hline \multicolumn{5}{|c|}{$\begin{array}{lcr}\text { bahwa nilai } & \text { rata-rata mahasiswa dalam } \\
\text { perekaman } & \text { EKG sebelum dilakukan } \\
\text { intervensi } & \text { pembelajaran } & \text { dengan }\end{array}$} \\
\hline \multicolumn{5}{|c|}{$\begin{array}{l}\text { menggunakan audio visual pada kelompok } \\
\text { perlakuan adalah } 73.27 \text { dan setelah } \\
\text { intervensi } 85.77 \text {. }\end{array}$} \\
\hline \multicolumn{5}{|c|}{$\begin{array}{l}\text { Sebelum dilakukan uji bivariat } \\
\text { pada nilai kompetensi mahasiswa maka } \\
\text { dilakukan uji normalitas untuk } \\
\text { menentukan uji yang akan digunakan. Uji } \\
\text { normalitas data menggunakan uji }\end{array}$} \\
\hline $\begin{array}{l}\text { Kolmogorc } \\
\text { normalitas }\end{array}$ & $\begin{array}{l}\text { rov-Smirn } \\
\text { s bisa dilil }\end{array}$ & & $\begin{array}{l}\text { Hasil } \\
\text { tabel } 4\end{array}$ & uji \\
\hline
\end{tabular}

Tabel 4

Hasil Uji Normalitas Data Nilai Pre dan Post Intervensi

\begin{tabular}{|c|c|c|c|}
\hline Variabel & Skweness & $\begin{array}{c}\text { Std. } \\
\text { Deviasi }\end{array}$ & $P$ \\
\hline Nilai Pre (Kontrol) & -0.956 & 6.90 & 0.000 \\
\hline $\begin{array}{l}\text { Nilai Post } \\
\text { (Kontrol) }\end{array}$ & 1.214 & 3.29 & 0.002 \\
\hline $\begin{array}{l}\text { Nilai Pre } \\
\text { (Intervensi) }\end{array}$ & -1.093 & 8.27 & 0.000 \\
\hline $\begin{array}{l}\text { Nilai Post } \\
\text { (Intervensi) }\end{array}$ & 0.106 & 4.77 & 0.017 \\
\hline
\end{tabular}


Berdasarkan tabel 4 menunjukkan bahwa nilai $p$ value semua variabel adalah $>0.05$. Nilai ini menunjukkan bahwa data terdistribusi tidak normal. Jika data terdistribusi tidak normal maka analisa data menggunakan Mann-Withney dan Wilxocon.

\section{Tabel 5}

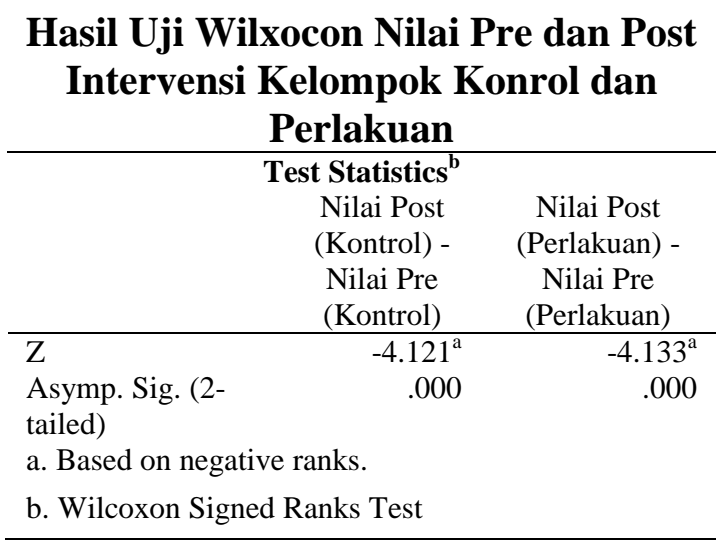

Berdasarkan tabel 5 diatas dapat dilihat bahwa nilai $p$ value kelompok kontrol setelah dan sebelum intervensi adalah 0.000 hal ini berarti $p$ value $<0.05$. Nilai ini menunjukkan bahwa ada perbedaan nilai sebelum dilakukan intervensi dan setelah dilakukan intervensi pembelajaran menggunakan phantom. Pada kelompok perlakukan nilai $p$ value adalah 0.000 hal ini berarti $p$ value $<0.05$. Nilai ini juga menunjukkan bahwa ada perbedaan nilai sebelum dilakukan intervensi dan setelah dilakukan intervensi pembelajaran menggunakan audio visual.

Sebelum dilakukan analisa data maka dilakukan uji Mann-Withney karena data terdistribusi tidak normal perlu dilakukan uji homogenitas. Uji homogenitas dilakukan untuk mengetahui apakah data homogen atau tidak.
Tabel 6

Hasil Uji Homogenitas pada Jenis

Kelamin, Usia, Nilai Post Intervensi pada Kelompok Konrol dan Perlakuan

\begin{tabular}{lc}
\hline Variabel & Nilai $p$ value \\
\hline Jenis Kelamin & 1.000 \\
Usia & 0.875 \\
Nilai Post Intervensi & 0.081 \\
\hline \multicolumn{2}{c}{ Tabel $\quad 6 \quad$ menunjukkan bahwa }
\end{tabular}
semua dapat memiliki nilai $\mathrm{p}$ value $>0.05$. Hal ini menunjukkan bahwa semua data homogen.

Tabel 7

\begin{tabular}{lr}
$\begin{array}{c}\text { Hasil Uji Mann-Withney Nilai Post } \\
\text { Intervensi Kelompok Konrol dan } \\
\text { Perlakuan }\end{array}$ \\
\hline \multicolumn{2}{c}{ Test Statistics $^{\mathrm{a}}$} \\
\multicolumn{2}{c}{ Nilai Post Tes } \\
\hline Mann-Whitney U & 130.000 \\
Wilcoxon W & 383.000 \\
Z & -2.707 \\
Asymp. Sig. (2-tailed) & .007 \\
a. Grouping Variable: Faktor &
\end{tabular}

Berdasarkan tabel 7 diatas dapat dilihat bahwa nilai $p$ value post intervensi pada kelompok kontrol dan perlakuan adalah 0.007. Hal ini menunjukkan bahwa nilai $p$ value $<0.05$ sehingga ada perbedaan nilai post intervensi pada kelompok kontrol dan kelompok perlakuan.

\section{PEMBAHASAN}

Hasil penelitian menunjukkan bahwa sebagian besar respon adalah perempuan baik itu pada kelompok perlakuan maupun kelompok kontrol. Fenomena yang ada di Indonesia adalah kebanyakan mahasiswa keperawatan memang perempuan. Usia responden juga rata-rata 19 tahun ini sesuai dimana pada tingkat 2 mahasiswa biasanya berusia lebih dari 19 tahun. 
Perbedaan Nilai Pre dan Post Intervensi pada Kelompok Kontrol dan Perlakuan

Hasil penelitian menunjukkan bahwa ada perbedaan yang signifikan pada nilai pre dan post intervensi baik itu pada kelompok kontrol maupun kelompok perlakuan. Hal ini berarti intervensi pembelajaran menggunakan phantom dan audio visual mempengaruhi pemahaman dan keterampilan responden dalam melakukan perekaman EKG. Mahasiswa akan memiliki pengetahuan yang lebih baik setelah dilakukan pembelajaran jika dibandingkan dengan kondisi dimana mereka belum terpapar suatu materi pembelajaran. Penelitian ini sesuai dengan penelitian yang dilakukan oleh Zaki (2009) dimana mahasiswa memiliki pengetahuan yang lebih baik setelah diberikan pembelajaran menggunakan role play contoh kasus, penayangan VCD dan modul dibanding sebelum dilakukan pembelajaran (Zaki, 2009). Penelitian ini juga didukung oleh penelitian Kholidati (2013) yang mendapatkan hasil bahwa penggunaan media audiovisual intranatal dan phantom sangat efektif untuk meningkatkan kemahiran dan ketrampilan mahasiswa (Kholidati, 2003).

Pembelajaran akan memberikan pengetahuan kepada seseorang, apapun bentuk pembelajaran tersebut. Hasil dari belajar adalah kapabilitias yang berarti akan terjadi peningkatan kemampuan individu sebagai hasil dari belajar. Kemampuan terjadi karena adanya stimulasidari lingkungan dan adanya proses kognitif dari pembelajaran. Pengetahuan merupakan hasil tau dari seseorang setelah mereka melakukan penginderaan terhadap sesuatu (Notoadmodjo, 2003). Pengalaman belajar yang semakin konkrit akan membuat hasil yang dicapai semakin tinggi.
Perbedaan Nilai Post Intervensi pada Kelompok Kontrol dan Perlakuan

Hasil penelitian menunjukkan bahwa ada perbedaan nilai post intervensi pada kelompok perlakuan dan kelompok kontrol. Hal ini berarti penggunaan media pembelajaran dengan audio visual memiliki pengaruh yang lebih baik pada kemampuan mahasiswa dalam melakukan perekama EKG dibanding dengan menggunakan media pembelajaran phantom. Penelitian ini sesuai dengan penelitian yang dilakukan oleh Lufianti (2010) yaitu terdapat perbedaan pengetahuan yang signifikan mahasiswa yang mendapatkan pembelajaran menggunakan phantom dengan mahasiswa yang mendapatkan pembelajaran menggunakan VCD. Pengetahuan mahasiswa yang mendapatkan pembelajaran menggunakan VCD lebih tinggi (Lufianti, 2010). Penelitian lain yaitu penelitian yang dilakukan oleh Kholidati (2003) dimana pembelajaran dengan media audiovisua lebih meningkatkan kemahiran kerja mahasiswa dibandingkan dengan phantom (Kholidati, 2003).

Penelitian ini juga sejalan dengan penelitian yang dilakukan oleh Satriyandari (2013) dimana mahasiswa yang diberikan pembelajaran menggunakan kombinasi VCD memiliki ketrampilan yang lebih baik dibandingkan dengan mahasiswa yang diberikan pembelajaran dengan media phantom. Media VCD memiliki keuntungan dibanding media lain yaitu dapat memperlihatkan secara langsung tentang proses ketrampilan. Melalui video tersebut materi akan mudah dipahami karena peragaan yang ditayangkan dijelaskan lebih terinci, gambar jelas dan bila 
mahasiswa kurang memahami dapat diputar ulang sehingga mahasiswa akan tertarik dengan materi yang dipelajari (Satyandari, 2013). Media audio visual termasuk VCD memiliki kemampuan lebih untuk menyampaikan pesan yang lebih lengkap, rumit, dan realistis. Selain itu penggunaan video lebih praktis, dapat diproduksi, relativ lebih murah, dan dapat didistribusikan kepada seluruh siswa (Basuki, 2001). Media audio visual adalah media instruksional modern yang sesuai dengan perkembangan jaman, meliputi media yang dapat didengar dan dilihat. Media audio visual dapat membuat konsep yang abstrak menjadi lebih kongkrit, dapat menampilkan gerak yang dipercepat atau diperlambat sehingga lebih mudah diamati, dapat menampilkan detail suatu benda atau proses, membuat penyajian pembelajaran lebih menarik, dan proses pembelajaran menjadi menyenangkan (Sanjaya, 2009).

Penelitian lain yang juga sejalan adalah penelitian yang dilakukan oleh didapatkan hasil bahwa mahasiswa yang mendapatkan pembelajaran dengan video (VCD) memiliki ketrampilan yang lebih tinggi dibandingkan dengan mahasiswa yang mendapatkan pembelajaran menggunakan media phantom (Agustin, 2011). Penelitian ini juga diperkuat oleh penelitian yang dilakukan oleh Haryoko (2009) dimana hasil belajar mahasiswa yang menggunakan teknik audio-visual lebih memiliki nilai yang tinggi dibandingkan dengan menggunakan teknik konvensional (Haryoko, 2009).

\section{KESIMPULAN DAN SARAN}

Berdasarkan hasil penelitian maka dapat ditarik kesimpulan bahwa Mahasiswa yang diberikan pembelajaran baik itu dengan menggunakan media pembelajaran audio visual atau phantom memiliki nilai ketrampilan memasang EKG yang lebih tinggi dibandingkan sebelum dilakukan pembelajaran. Mahasiswa yang diberikan pembelajaran dengan menggunakan media pembelajaran audio visual memiliki nilai ketrampilan memasang EKG yang lebih tinggi dibandingkan dengan mahasiswa yang diberikan pembelajaran dengan menggunakan media pembelajaran phantom.

Berdasarkan simpulan dari hasil penelitian ini disarankan bagi pendidik dapat dijadikan data awal untuk melakukan penelitian lain terkait metode pembelajaran yang tepat.Bagi pendidik diharapkan dapat menerapkan media pembelajaran audio-visual dalam melakukan pembelajaran pada mahasiswa. Bagi mahasiswa dengan adanya media audio visual diharapkan dapat memiliki ketrampilan yang lebih baik dalam melakukan pelayanan keperawatan.

\section{DAFTAR RUJUKAN}

Agustin, Y.D. (2011). Perbedaan Keefektifan Penggunaan Media Pembelajaran Video dengan Fantom dalam Meningkatkan Keterampilan Pemasangan Kateter pada Mahasiswa (Thesis). Surakarta : Universitas Sebelas Maret.

Azha, A. (2005). Media Pembelajaran. Jakarta : PT. Raja Grafindo Persada.

Basuki,W., \& Farida, M. (2001). Media Pengajaran. Bandung : $\mathrm{Cv}$. Maulana.

Burke, W.J. (2005). Competency Based Education and Training. London : The Falmer Press. 
Dharma, K. (2011). Metodologi Penelitian Keperawatan : Pedoman Melaksanakan dan Menerapkan Hasil Penelitian. Jakarta : Trans Info Media.

Dharma, S. (2010). Pedoman Praktis Interpretasi EKG. Jakarta : EGC.

Djamarah, S. B., \& Aswan, Z. (2006). Strategi Belajar Mengajar. Jakarta : PT. Rineka Cipta.

Haryoko, Sapto. (2009). Efektivitas Pemanfaatan Media AudioVisual Sebagai Alternatif Optimalisasi Model Pembelajaran. Jurnal Edukasi Elektro, 5 (1). p.1-10.

Hasan, I. (2006). Analisa Data Penelitian dengan Statistik. Jakarta : Bumi Aksara.

Hidayat, A.A. (2007). Metode Penelitian Keperawatan dan Tekhnik Analisa Data. Jakarta : Salemba Medika.

Kholidati, R. (2003). Pengaruh Penggunaan Media Audiovisual Intranatal dan Phantom terhadap Tingkat Kemahiran Unjuk Kerja Keterampilan Vaginaltoucher (VT) dan Intranatal Care (Suatu Eksperimen di Prodi S1 Keperawatan STIKes Hutama Abdi Husada Tulungagung) (Skripsi). Surakarta : Universitas Negeri Surakarta.

Lutfianti, A. (2010). Perbedaan Pengaruh Pembelajaran Perawatan Payudara (Breast Care) Dengan Video Compact Disc (VCD) Dibanding Dengan Phantom terhadap Pengetahuan dan Motivasi Belajar (pada Mahasiswa D - III Keperawatan Sekolah Tinggi Ilmu Kesehatan An - Nur Purwodadi) (Thesis).
Surakarta : Universitas Negeri Surakarta.

M. Suyanto. (2003). Multimedia Alat Untuk Meningkatkan Keunggulan Bersaing. Yogyakarta : Andi.

Notoatmodjo, S. (2003). Pendidikan dan Perilaku Kesehatan. Jakarta : Rinek Cipta.

Oemar, H. (2003). Kurikulum dan Pembelajaran. Jakarta : Bumi Aksara.

Rudi Susialana, dkk. (2008). Media Pembelajaran. Bandung : CV. Wacana Prima.

Sanjaya. 2009. Strategi Pembelajaran Berorientasi Standar Proses Pendidikan Ed. I. Jakarta : Kencana Prenada Media Group.

Satyandari, Y., Mufdlilah, \& Ririn W.H. (2013). Pengaruh Media Pembelajaran Demonstrasi Phantom Dibanding Kombinasi Video Compact Disc Terhadap Ketrampilan Injeksi Mahasiswa. Jurnal Kebidanan dan Keperawatan, 9 (2). p.155-162.

Sugiyono. (2012). Metode Penelitian Pendidikan (Pendekatan Kuantitatif, Kualitatif, dan $R \& D)$. Bandung : Alfabeta.

Usman, M.Uzer. (2006). Menjadi Guru Professional. Bandung : Remaja Rosdakarya.

Yudhi, M. (2012). Media Pelajaran. Jakarta : Gaung Persada.

Zaki, R., Sri W., \& Fatwa S.T.D. (2009). Efektivitas Role Play, Penayangan Vcd Dan Modul Dalam Meningkatkan Keterampilan Komunikasi Terapeutik Mahasiswa Stikes Jenderal Ahmad Yani Yogyakarta. Berita Kedokteran Masyarakat, 25 (3). p.125-132. 